\title{
ANALISA NUMERIK PEMILIHAN GEOMETRI FIN BURITAN UNTUK KAPAL-KAPAL SPEED BOAT YANG BEROPERASI DI AMBON DAN SEKITARNYA
}

\author{
Eliza. R. de Fretes \\ defretesera@gmail.com \\ Jurusan Teknik Perkapalan Fakultas Teknik Unpatti
}

\begin{abstract}
ABSTRAK
Kapal speed boat merupakan kategori kapal cepat yang mempunyai kecepatan dinas yang tinggi, ini ditandai dengan Froude Number (Fn) yang lebih besar dari 1.2. Dalam pengoperasiannya speed boat mempunyai permasalahan yang sangat kruisal tentang trim, dimana pada kondisi kapal kosong sering kali mengalami trim buritan sehingga nahkoda tidak dapat melihat ke depan, adanya hambatan yang besar, serta arah kemudi yang sulit dikemudikan. Selain itu pada saat mulai berjalan speed boat mempunyai kecenderungan menukik ke haluan, hal inipun perlu untuk mendapat perhatian khusus.

Kajian yang disampaikan dalam penelitian ini mengkaji variasi sejumah bentuk dan konfigurasi bentuk peralatan peredam trim yang digunakan pada speed boat, lebih khususnya dengan meninjau pada pola aliran yang terbentuk dan lift yang ditimbulkan. Pengkajian dilakukan dengan menerapkan pemodelan numerik, selanjutnya hasil numerik divalidasi dengan pengujian laboratorium untuk mendapatkan hasil yang menyerupai kondisi sebenarnya. Setelah itu kapal dirancang dan dibuat dalam bentuk prototype.

Hasil yang diperoleh untuk aerofoil foil buritan dengan type NACA 010 mendapat gaya lift sesuai dengan kemiringan nya yaitu 5 derajat, panjang foil 10\% panjang garis air, serta koefisien kecepatan kapal antara 2 sampai dengan 7 knot, koefisien lift yang diperoleh adalah 0,003; koefisien drag adalah 0,007, serta koefisien momen yang dihasilkan adalah 0,01; Pada kemiringan 10 derajat mempunyai koefifien lift 0,009 dan koefisien drag 0,015, akan tetapi koefisien momen mendfapat nilai nol, sedangkan yang diperlukan adalah besarnya momen untuk mengangkat kapal
\end{abstract}

Kata Kunci:speed, boat, lift, trim

\section{PENDAHULUAN}

Kapal speed boat merupakan kategori kapal cepat yang mempunyai kecepatan dinasyang tinggi dengan Froude number lebih besar dari 1.2, digunakan oleh petugas dalam rangka memberikan pertolongan bila terjadi kecelakaan / musibah, dan atau inspeksi/pemeriksaan di alur pantai, sungai, danau dan penyeberangan. (Hadi dan Jokosisworo, 2012). Dalam pengoperasiannya speed boat mempunyai permasalahan yang sangat kruisal tentang trim, dimana pada kondisi kapal kosong sering kali mengalami trim buritan sehingga nahkoda tidak dapat melihat ke depan, adanya hambatan yang besar diakibatkan karena daerah luasan permukaan dan aliran yang terjadi mempunyai titik staknasi yang besar, serta arah kemudi yang sulit dikemudikan. Selain itu pada saat mulai berjalan speed boat mempunyai kecenderungan menukik ke haluan, hal inipun perlu untuk mendapat perhatian khusus.

Selain itu pada kapal cepat bila dilihat dari bentuk konstruksi desainnya memiliki sudut deadrise (angle of deadrise). Menurut Savitsky [Faltinsen, O.M, "Hydrodynamics of High Speed Marine Vessel"Cambridge University Press, New York (2005). Bila gaya angkat mendekati nol, maka demikian pula sudut trim yang dibentuk, juga akan mendekati nol. Sehingga sudut trim memiliki fungsi yang serupa dengan sudut serang pada teori hidrodinammik. Lebih jauh bila gaya angkat menurun secara linear, maka akan meningkatkan sudut deadrise. Sehingga dapat diketahui bahwa sudut deadrise memiliki hubungan langsung dengan gaya angkat (lift).

Penelitian ini berdampak positif untuk :

- Pengusaha Transportasi laut, terutama tentang keselamatan dan konstruksi serta perbaikan kapal serta pengiritan bahan bakar

- Pengemudi Speed boat, karena tidak menghalangi pandangan di depan

- Pengguna Speed boat, karena mengurangi ketidak nyamanan yang diakibatkan oleh hentakan kapal 


\section{KAJIAN TEORI DAN METODE}

Sebelum memulai suatu kapal, maka perlu dibahas terlebih dahulu tentang jenis-jenis kendaraan laut yang lingkupnya meliputi kapal yang didukung oleh hidrostatik dan hidrodinamik. Pengaruh kedua komponen ini terhadap berbagai jenis kapal yang diatas permukaan, semisubmersible maupun kapal selam. Selain itu single hull, multi hull serta planing hull (Watson, 1998).

Suatu kapal cepat khususnya pada kapal cepat dengan ukuran kecil ketika dioperasikan akan mengalami kondisi berikut [Savitsky Daniel, Ward Brown P. "Procedures for Hydrodynamis Evaluation of Planing Hulls in Smooth and Rough Water", Marine Technology, Vol 13 No.4 (1976). :

a. Pada kondisi saat kapal diam dan bergerak pada kecepatan rendah, kapal cepat (planning boat) tersebut memiliki sifat sebagai layaknya lambung displasemen (Displacement Hull). Pada kondisi ini keseluruhan gaya angkat (lift) yang bekerja pada lambung berasal dari gaya apung (Bouyant forces).

b. Sebagaimana kecepatan yang meningkat, akan berdampak pada pada koefisien kecepatan yang merupakan fungsi dari lebar rata rata kapal dan kecepatan serta percepatan grafitasi. Pada saat kapal berada pada nilai koefisien kecepatan mencapai 0,5 , akan terjadi penurunan resultan gaya hidrodinamik. Bila dibandingkan dengan gaya statis murni dikaitkan dengan letak tinggi sarat dan trim kapal

c. Pada koefisien kecepatan antara 0,5 hingga 1,5 pengaruh dinamik menghasilkan nilai tambah yang positif terhadap gaya angkat (lift), meskipun pada sebagian besar kasus, tidak terjadi kenaikan yang signifikan pada pusat grafitasi atau kenaikan pada bagian depan haluan

d. Pada koefisien kecepatan yang lebih besar dari 1,5, suatu kapal cepat akan memiliki gaya angkat dinamik yang akan menghasilkan kenaikan yang signifikan pada pusat grafitasi,trim, dan semakin meningginya haluan

Perhitungan ini menggunakan metode Savitsky (1984). Metode ini cocok diaplikasikan pada kapal cepat terutama pada kapal cepat bentuk hard chine, perhitungannya dilakukan dengan menggunakan Froude number.

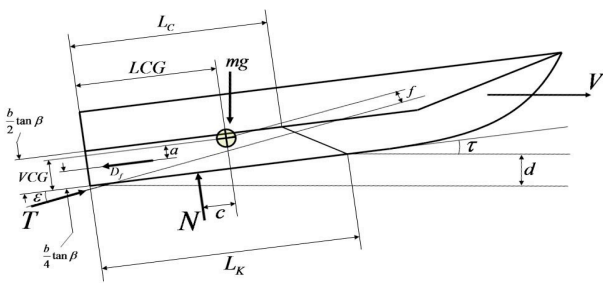

Gambar 1 Kapal saat planing hull

$$
\begin{aligned}
& \mathrm{N} \cos \tau+\mathrm{T} \sin (\tau+\varepsilon)-\mathrm{mg}-\mathrm{D}_{\mathrm{f}} \sin \tau=0 \\
& \mathrm{~T} \cos (\tau+\varepsilon)-\mathrm{N} \sin \tau-\mathrm{D}_{\mathrm{f}} \cos \tau=0 \\
& \mathrm{CG} \quad: \mathrm{N} . \mathrm{c}+\mathrm{D}_{\mathrm{f} . \mathrm{a}}-\mathrm{T} . \mathrm{f}=0
\end{aligned}
$$

Kapal cepat pada saat beroperasi, mulai dari kecepatan (V) 0 knot sampai dengan kecepatan tinggi (kecepatan maksimum) dapat di lihat akan melampaui tiga tahapan (fase) kecepatan sebagai berikut:

\section{a. Fase displasemen $(0,0<$ Fn $<0,6)$}

Kapal-kapal komersial besar hampir selalu berlayar pada fase ini, dimana berat kapal seluruhnya disangga oleh gaya angkat (buoyancy). Kapal yang berlayar dengan kecepatan cukup rendah $(\mathrm{Fn}<0,3)$ tidak akan mengalami perubahan trim ataupun penurunan titik berat (VCG) yang berarti. Dengan naiknya kecepatan (Fn) perubahan tersebut mulai timbul. Perubahan ini terjadi akibat naiknya aliran karena bertambah terbenamnya kapal, yang selanjutnya sesuai Hukum Bernoulli, akan berakibat pada penurunan tekanan di bawah kapal bagian buritan dan kenaikan tekanan di bawah haluan kapal.

\section{b. Fase pre-planing $(0,6<$ Fn $<1,2)$}

Pada fase pre-planing berat kapal akan disangga lebih banyak oleh gaya angkat hidrodinamik. Gaya angkat hidrodinamik ini timbul karena adanya deviasi aliran di sekitar dasar kapal bagian buritan, sehingga mengakibatkan kapal trim. Dari berbagai pengukuran tes model didapat bahwa pada fase ini titik berat kapal akan naik. Pada sekitar Fn $=0.6$, VCG mencapai ketinggian yang sama dengan pada saat $\mathrm{V}=0$ knot dan selanjutnya VCG terus naik sampai kecepatan karakteristik Fn $=1,2$ dicapai. Dari kecepatan $\mathrm{v}=0$ knot sampai dengan $\mathrm{Fn}=0,9$ haluan kapal akan terus naik ke arah permukaan, sedangkan buritanya akan berangsur-angsur terbenam. Pada sekitar $0,9<\mathrm{Fn}$ $<1,2$ buritan kapal akan mulai naik lagi, tetapi tidak begitu besar sampai dengan munculnya 
haluan. Dengan demikian trim akan tetap naik sampai dengan $\mathrm{Fn}=1,2$ dicapai.

\section{c. Fase planing $(\mathrm{Fn}>1,2)$}

Fase planning dapat ditandai dengan kondisi dimana hampir seluruh berat kapal disangga oleh gaya angkat hidrodinamik, dan hanya sebagian kecil berat kapal yang bertumpu pada gaya hidrostatik yang juga kecil. Meskipun kapal hampir seluruhnya meluncur di permukaan air, dan permukaan basahnya menjadi sangat kecil demikian juga trim kapal mulai menurun dibandingkan dengan pada fase pre-planing, tetapi tekanan hidrodinamik menjadi sangat besar sebagai akibat kecepatan tinggi yang diperoleh dari gaya dorong propeller. Pada fase planing, bagian kapal yang terbenam sangat kecil, sehingga gelombang yang terbentuk hampir hilang samasekali.

Bentuk planing hull paling sederhana adalah bidang datar yang diilustrasikan pada gambar 5 . Pengaruh penting dari aliran adalah tinggi water level permukaan air tenang sebagai akibat dari planing. Akibatnya panjang permukaan basah yang dinamis ( L ) lebih besar dari pada yang terendam ( $\mathrm{Li}$ ). Kedua panjang ini berbeda dengan panjang stasioner (Lo). Leading edge dari permukaan basah secara nominal didefinisikan oleh lokasi spray-root line. Kelengkungan permukaan biasanya diabaikan dalam perhitungan.

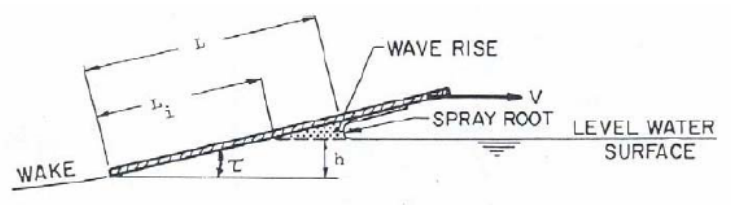

Gambar 2. Geometri sederhana dari permukaan planning (Savitsky, 1964)

\section{HASIL DAN PEMBAHASAN}

Transportasi jarak dekat di daerah Maluku pada umumnya menggunakan kapal cepat seperti diperlihatkan pada gambar 3. Rute yang dilewati yaitu rute Ambon-Wayame, Ambon-Kotajawa, Tulehu-Desa-desa di pulau Haruku, Tulehu-Haria, Tulehu-Amet (pulau Nusalaut). Rata-rata kapal cepat yang beroperasi mempunyai dua konfigurasi ukuran panjang 7,45 meter dan 4 meter. Jumlah penumpang yang diangkut adalah 20 orang, selain itu untuk kapal cepat kecil daya angkutnya adalah 6 orang. Untuk penelitian ini dikhususkan untuk kapal-kapal dengan ukuran 7,45 m. Pengoperasian kapal pada kecepatan tinggi, dengan jumlah penumpang yang kurang, kapal mengalami trim butitan yang sangat besar sehingga dapat mengganggu penglihatan dari jurumudi. Selain itu pada kondisi tersebut jika pada kondisi gelombang maka akan terjadi hentakan, maupun dapat menyebabklan capzasing yang dapat menyebabkan keselamatan dari kapal tersebut dapat diganggu, baik untuk kapal itu sendiri maupun untuk penumpang.

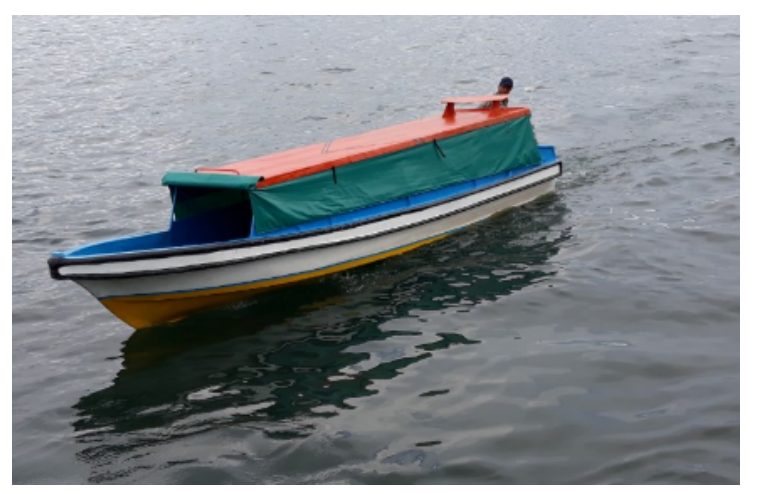

Gambar 3. Kapal cepat yang beroperasi di Teluk Ambon

Kapal-kapal ini dalam pengoperasiannya mempunyai tingkat keselamatan yang sangat riskan, pada tinggi gelombang $1 \mathrm{~m}$ dengan panjang gelombang yang pendek atau sama dengan panjang kapal. Kondisi ini sangat kritis karena mengganggu kapal terhadap stabilitas, maupun kekuatan dan kostruksi kapal. Selain itu pengaturan kecepatan perlu untuk mendapat perhatian guna dapat mengurangi kecepatan atau menyesuaikan kecepatan kapal dengan kondisi perairan yang dilewati oleh kapal.

Dari data kapal yang telah dibangun yang beroperasi di ambon dan sekitarnya, diperoleh ukuran pokok kapal untuk panjang dilakukan dengan menggunakan optimisasi, dengan menggunakan database dari kapal-kapal yang melayari. Selanjutnya dari ukuran panjang tersebut sebagai acuan diperoleh lebar, panjang garis air dan ukuran serta koefisien bentuk lainnya. Koefisien bentuk didasarkan dengan menggunakan pendekatan empiris dari data statistik. Serta pengecekan deplasemen kapal yang antara deplasement ukuran pokok dan komponen berat atau dengan kata lain penjumlahan DWT dan LWT. Hasil analisanya dapat ditentukan demikian : 
- Panjang Kapal (LOA) : 7,45 m

- Panjang Garis Air $\quad: 7,068 \mathrm{~m}$

- Lebar Kapal : $1,513 \mathrm{~m}$

- Tinggi geladak $: 1,15 \mathrm{~m}$

- Tinggi Sarat $: 0,4 \mathrm{~m}$

- Deplasemen : 1,925 Ton

- Koefisen blok : : 0,543

- Koefisien Water line : 0,821

- Koefisien mid ship : 0,74

- Koefisen Prismatik : :0,736

- LCB : 3,237 m aft

Dari hasil analisa dan ukuran pokok yang diperoleh pada proses desain kapal, penggambaran rencana garis dilakukan. Dengan menggunakan luas bidang gading dan luas bidang garis air, dan pengecekan terhadap Tinggi titik tekan memanjang kapal (LCB) dimana penggambaran gading dilakukan secara manual dan memperoleh gambar body plan secara manual yang merupakan dasar dari proyeksi rencana garis. Setelah melalui penggambaran pada program numerik maxsurf, maka diperoleh ukuran pokok kapal sebagai pengecekan terhadap hasil desain.

gambar rencana garis sebenarnya. Hasil yang diperoleh adalah seperti pada Gambar 4 berikut ini :

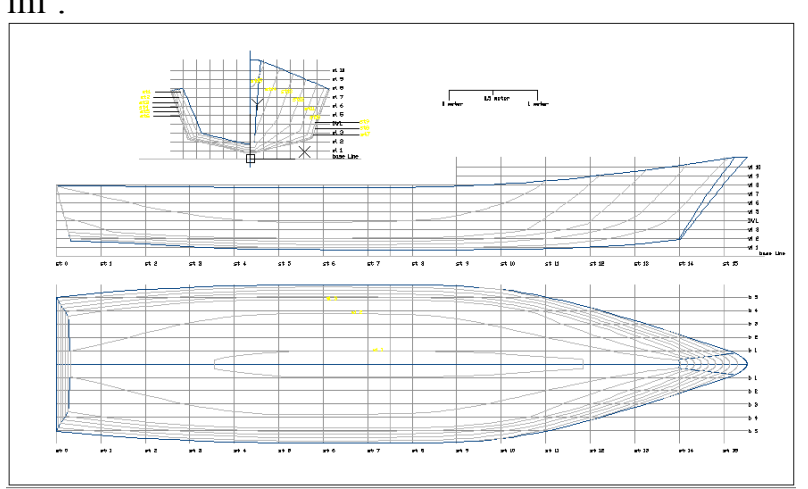

Gambar 4. Rencana Garis kapal.

Setelah perhitungan dan penggambaran rencana garis, maka dilakukan perhitungan fisik suatu kapal untuk menentukan karakteristik dari suatu kapal dalam bentuk diagram hidrostatis yang dapat dilihat pada gambar 5 dibawah ini. Perhitungan ini harus diperiksa kembali ukuran pokok dan koefisien bentuk tentang kesesuaian ukuran pada waktu desain dengan ukuran pokok dan koefisien bentuk yang dihitung pada hidrostatis, jika perhitungannya telah memenuhi toleransi yang diberikan, maka perhitungan hidrostatis tersebut dapat dipakai sebagai dokumen dan karakteristik dari kapal tersebut.
Seterusnya dapat dilakukan perhitungan lanjutan dalam proses desain, terutama perhitungan hambatan dan hidrodinamis serta penentuan tenaga mesin induk yang merupakan masalah pokok yang ditinjau dalam penelitian ini

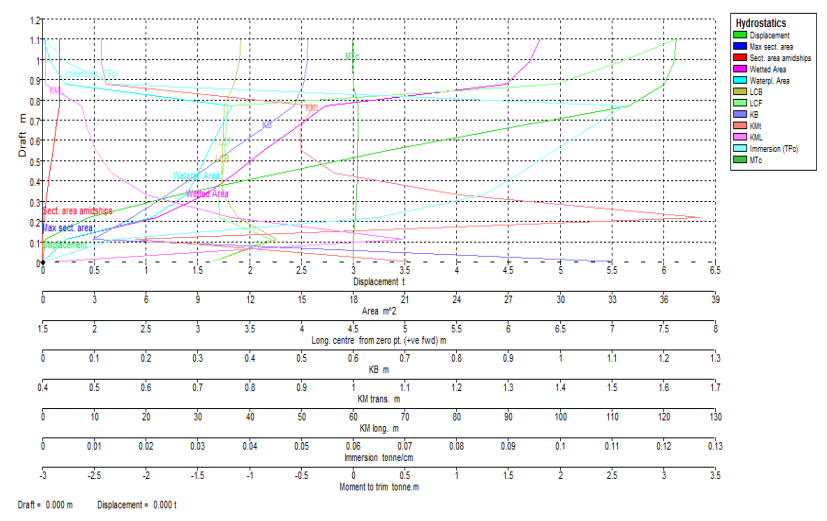

Gambar 5. Diagram hidrostatis kapal

Hasil perhitungan tahanan dan tenaga motor induk efektif untuk menentukan ukuran dan tipe system propulsor yang terpakai di kapal. Selain itu analisa hidrodinamika dari kapal, dimana pada kecepatan lebih kecil dari 7 knot, maka kapal ini belum mencapai preplanning, sementara kecepatan 7-13 knot kapal ini mengalami preplanning dan pada kecepatan lebihbesar dari 13 knot kapal ini mengalami planning. Dengan kata lain bahwa efek hidrodinamik atau gaya lift dari kapal ini mulai bekerja pada kecepatan 7 knot dan sempurna mulai pada kecepatan 13 knot. Karakteristik untuk kapal cepat didefinisikan oleh besarnya bilangan Froude yakni Fn $>0,4$. (Bero, 2009). Umumnya yang mendominasi gaya hidrodinamika kapal adalah gaya apung, untuk kapal yang mempunyai $\mathrm{Fn}>1,0$, gaya hidrodinamika mempunyai kecendrungan yang sangat besar sehingga berat kapal direduksi oleh gaya apung

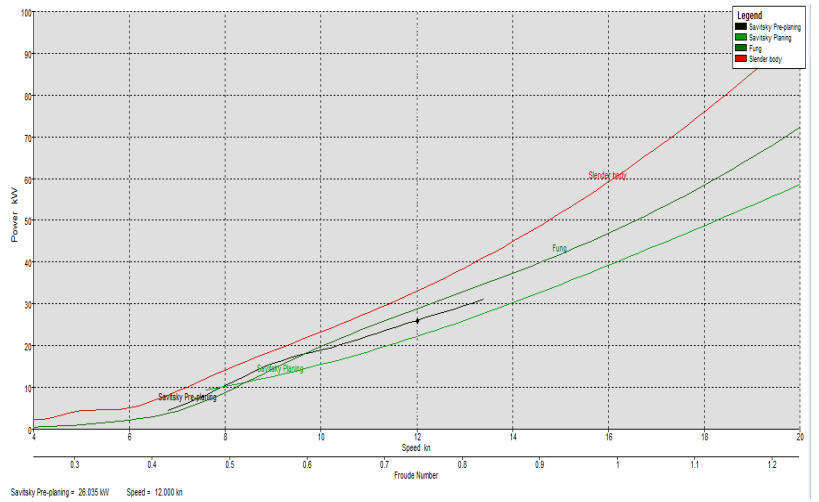

Gambar 6. Grafik Hambatan Kapal 
Gambar 6 diatas, memperlihatkan bahwa pada Froude number $(\mathrm{Fn})<0.42$ kapal mengalami kondisi kecepatan displasemen. Untuk kapalkapal kecil diperhitungkan dengan menggunakan metode Fung. Untuk kecepatan kapal 6,3 m/dt (13 knot pada $F n=0,42$ ) diperoleh besar hambatan 4000 Watt kecenderungan kemiringan kurva hambatan adalah linier dari kecepatan $4 \mathrm{~m} / \mathrm{dt}$ sampai dengan $6,35 \mathrm{~m} / \mathrm{dt}$ kemringannya dari 500 Watt sampai dengan 4000 Watt, sedangkan untuk $0,42<\mathrm{Fn}<0,82$ kapal mengalami Pre planing pada kecepatan $6,3 \mathrm{~m} / \mathrm{dt}$ sampai dengan $8,5 \mathrm{~m} / \mathrm{dt}$ kecendrungan kurva meningkat dan setelah itu kecenderungan kurva cenderung kurva meningkat secara linier sampai dengan 13,3 meter/dt atau Fn 0,82 , sedangkan $0,82<$ Fn kapal mengalami planing. Ada sedikit loncatan pada Fn 0,82 dari preplaning ke planing hull. Peningkatan hambatan untuk planing hull kenaikannya secara linier untuk Fn 0,82 dengan kemiringan landai.

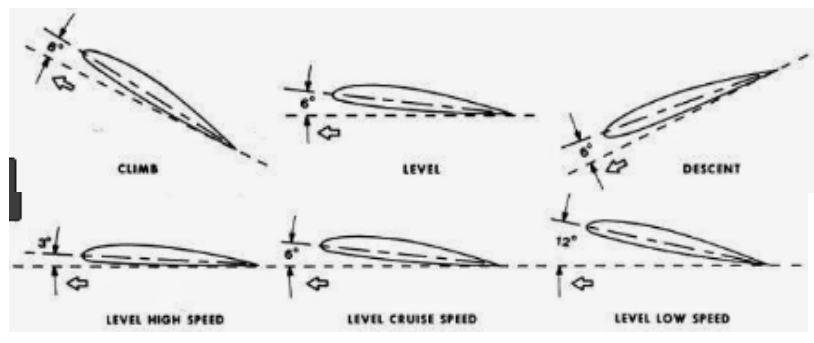

Gambar 7. Kedudukan airfoil yang disesuaikan dengan kecepatan

Pengujian Airfoil dengan menggunakan metode CFD yang merupakan variasi kecepatan serta variasi sudut leading edge pada type NACA 010 , hasilnya dapat dilihat pada Gambar 8 berikut ini :

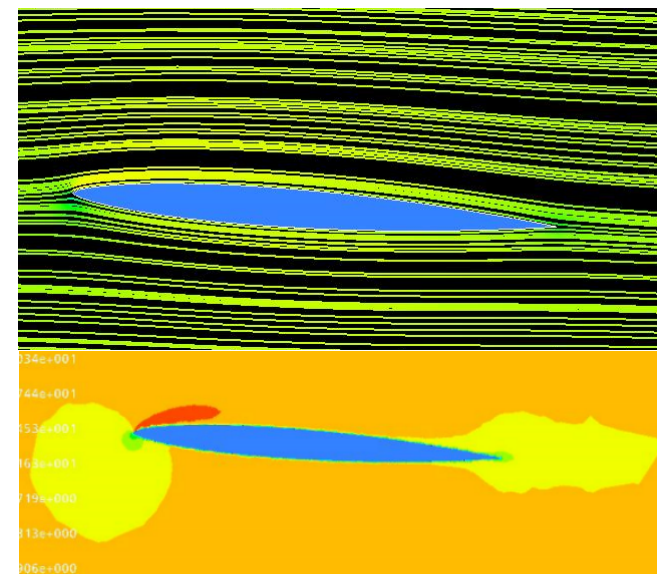

a) Stream function aliran

b) b) Vektor kecepatan

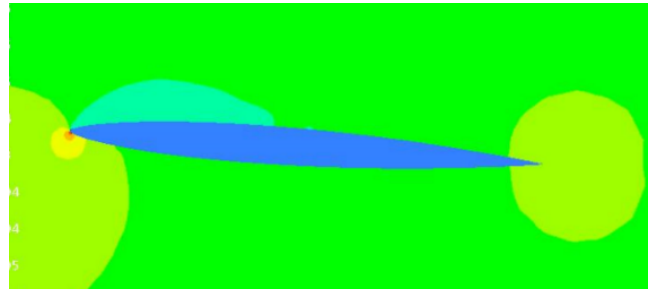

a. Distribusi Tekanan yang terjadi Gambar 8. Hasil Pengujian Aerofoil untuk sudut 5 derajat, dengan kecepatan $20 \mathrm{~m} / \mathrm{dt}$

Untuk Naca 010, diperoleh koefisien gaya lift, drag dan koefisien momen yang dihasilkan oleh Aerofoil seperti diperlihatkan pada tabel 3 berikut ini :

Tabel 3. Data Perhitungan CD, CL, CM

\begin{tabular}{|l|l|l|l|l|l|l|l|}
\hline No & $\begin{array}{l}\text { Angel of } \\
\text { Attack }\end{array}$ & Rpm & CD & CL & CM & h & V free stream \\
\hline 1 & -5 & 2496 & 0,006 & 0,000 & 0,001 & 3,5 & 40,764 \\
\hline 2 & $-2,5$ & 2508 & 0,005 & 0,000 & 0,002 & 3,5 & 40,764 \\
\hline 3 & 0 & 2506 & 0,005 & 0,001 & 0,001 & 3,5 & 40,764 \\
\hline 4 & 2,5 & 2499 & 0,006 & 0,002 & 0,001 & 3,5 & 40,764 \\
\hline 5 & 5 & 2502 & 0,007 & 0,003 & 0,001 & 4 & 46,587 \\
\hline 6 & 7,5 & 2503 & 0,009 & 0,004 & 0,000 & 4 & 46,587 \\
\hline 7 & 10 & 2509 & 0,015 & 0,006 & 0,000 & 3,5 & 40,764 \\
\hline 8 & 12,5 & 2503 & 0,017 & 0,007 & 0,000 & 3,5 & 40,764 \\
\hline 9 & 15 & 2499 & 0,023 & 0,008 & 0,001 & 3,5 & 40,764 \\
\hline 10 & 17,5 & 2509 & 0,026 & 0,009 & 0,001 & 3,5 & 40,764 \\
\hline 11 & 20 & 2502 & 0,035 & 0,010 & 0,001 & 3,5 & 40,764 \\
\hline 12 & 22,5 & 2498 & 0,040 & 0,008 & 0,001 & 3,5 & 40,764 \\
\hline
\end{tabular}

\section{KESIMPULAN}

Dari pembahasan diatas dapat disimpulkan bahwa:

1. Pemasangan foil buritan mendapat gaya lift sesuai dengan kemiringan nya yaitu 5 derajat, panjang foil $10 \%$ panjang garis air, serta koefisien kecepatan kapal antara 2 sampai dengan 7

2. Koefisien lift yang diperoleh adalah 0,003; koefisien drag adalah 0,007 , serta koefisien momen yang dihasilkan adalah 0,01

3. Pada kemiringan 10 derajat mempunyai koefifien lift 0,009 dan koefisien drag 0,015, akan tetapi koefisien momen mendfapat nilai nol, sedangkan yang diperlukan adalah besarnya momen untuk mengangkat kapal

\section{DAFTAR PUSTAKA}

Anuar Bin Bero, May 2009 "Performance Prediction For High Speed Craft" A dissertation submitted in partial fulfillment of the requirements for the award of the degree of Master of Engineering (Marine Technology), Faculty of Mechanical Engineering Universiti Teknologi Malaysia 
Irfan Syarif Arief et al., 2010 “ Analisa Pengaruh Cekungan Yang Diterapkan Pada Plat Datar terhadap Aliran Fluida Untuk Mendukung Teknologi Maritim Pendekatan CFD"Jurusan Teknik Sistem Perkapalan, Institut Teknologi Sepuluh Nopember Surabaya

Muchammad., 2006 "Perhitungan Gaya Drag Pada Benda Uji Pelat Persegi Datar Menggunakan Low Speed Wind Tunnel"Momentum, Vol. 2, No. 1, April 2006 : $15-25$

Savitsky D, 1964 " Hydrodynamic Design Of Planing Hull", Marine Technology, Vol I, No 1, pp 71-95, October

Savitsky D, Brown P.W., 1976 "Procedure of Hydrodynamic Evaluation Of Planing Hull In Smooth and Rought Water", Marine Technology, Vol 13, No 4, Oct 1976, pp 381-400

Sukoco., 2015“ Upaya Peningkatan Gaya Angkat Pada Model Airfoil Dengan Menggunakan Vortex Generator", Jurnal Teknik Vol. 5 No. 2 /Oktober, ISSN 2088 - 3676

Tuncer A, Tayar G. T., and Unsan Y. 2016," Interceptor Design And Control For The High Speed Craft", GiDB DERGi Sayı 7 